\title{
ANALISIS CAKUPAN PEMERIKSAAN IVA TEST DAN PAP SMEAR PADA PASANGAN USIA SUBUR
}

\author{
Rahmawati Mading', Siti Saleha², Cipta Pramana ${ }^{*}$ \\ ${ }^{1}$ Program Pascasarjana Kebidanan STIKES Guna Bangsa Yogyakarta \\ ${ }^{2}$ Program Studi Kebidanan Universitas Islam Negeri Alauddin Makassar \\ *Corresponding author: pramanacipta@yahoo.com
}

\begin{abstract}
The Inspection Visual Acetic acid (IVA) and Pap smear tests in Benteng sub-district are still lacking and very minimal. This study aims to find out how the scope of the IVA test and Pap smear examinations for couples of childbearing ages in Benteng Kepulauan Selayar District in 2021. The type of research used is descriptive analytic with a cross-sectional research design by making couples of childbearing ages as the research sample. The target in the Benteng Health Center area with non-probability sampling technique and accident sampling technique, totaling 93 people. The research used univariate data analysis with frequency distribution tables, bivariate analysis with chi-square technique. The results of the bivariate analysis showed that there was a significant relationship between age and the IVA and Pap smear tests $(p=0.029)$, there was no significant relationship between education and the IVA and Pap Smear tests $(p=0.049)$, there was a significant relationship between knowledge and the tests. IVA and Pap Smear $(p=0.027)$, there was a significant relationship between attitudes with the VIA and Pap Smear tests $(p=0.020)$, and there was a significant relationship between husband's support with the VIA and Pap Smear tests $(p=0.017)$. The conclusion of this research is from the coverage analysis that greatly affects the success of the IVA test and pap smear examination, it is the husband's involvement or husband's support.
\end{abstract}

Keywords: IVA test, Pap Smear test, Elderly Age Couple

\section{PENDAHULUAN}

Penyakit kanker merupakan salah satu penyebab kematian utama di seluruh dunia. Pada tahun 2012, kanker menjadi penyebab kematian sekitar 8,2 juta orang. Berdasarkan data International Agency for Research on Cancer (IARC) diketahui bahwa pada tahun 2012 terdapat 14.067.894 kasus baru kanker dan 8.201.575 kematian akibat kanker di seluruh dunia. Diperkirakan pada tahun 2030 insiden kanker dapat mencapai 26 juta orang dan 17 juta diantaranya meninggal akibat kanker, terlebih untuk negara miskin dan berkembang kejadiannya akan lebih cepat $^{1}$.

Berdasarkan data World Health Organization (WHO) tahun 2008 penyakit kanker serviks menempati urutan teratas di antara berbagai jenis kanker penyebab kematian pada perempuan di dunia, terdapat 490.000 perempuan didunia setiap tahun didiagnosa terkena kanker serviks, 240.000 diantaranya mengalami kematian ${ }^{2}$.

Kemenkes menyatakan sejak dicanangkan menjadi program nasional pada tahun 2008, cakupan metode dan pemeriksaan yang menyasar wanita usia 30-50 tahun tersebut terus mengalami peningkatan. Cakupan deteksi dini IVA di tahun 2016 meningkat menjadi 1.925 .943 orang $(5,1 \%)$ dibandingkan dengan cakupan tahun 2015 yang berjumlah 1.268.333 orang (3.4\%) (8). Sejak tahun 2007 sampai dengan 2016 sudah dilakukan deteksi dini kanker serviks terhadap 1.925.943 atau sekitar
$5,15 \%$ perempuan usia 30-50 tahun. Pemeriksaan dilakukan menggunakan metode pemeriksaan Inspeksi Vistual Asam Asetat (IVA) atau Pap Smear. Cakupan pemeriksaan IVA tertinggi terdapat di Bali yaitu sebesar 19,57\%, diikuti oleh DKI Jakarta sebesar 12,09\%, dan Nusa Tenggara Barat sebesar $11,42 \%{ }^{3}$.

Masih minimnya kesadaran masyarakat Indonesia terutama perempuan tentang kanker menyebabkan rendahnya angka deteksi dini kanker oleh perempuan ${ }^{4}$. Banyak faktor yang mempengaruhi rendahnya perilaku seseorang untuk melakukan deteksi dini kanker serviks. Menurut Evennet, rasa takut akan diketahuinya penyakit kanker yang dialami mengakibatkan seseorang menghindari melakukan deteksi dini. Perasaan malu, khawatir, atau cemas untuk menjalani pemeriksaan IVA karena ada pikiran tentang ada orang lain selain pasangan yang memasukkan sesuatu ke dalam dirinya, sehingga mempengaruhi wanita untuk tidak IVA ${ }^{5}$. Hal ini sejalan dengan hasil penelitian Nisa yang menyatakan bahwa sebagian responden tidak ingin menjalani pemeriksaan IVA karena mereka merasa malu dan tidak nyaman dengan metode pemeriksaan IVA karena dilakukan pada organ kewanitaan bagian dalam 6 .

Kecamatan Benteng hanya memiliki satu unit Puskesmas, dan telah melaksanakan program deteksi dini kanker servik dengan metode IVA. Pada tahun 2020 Kecamatan Benteng memiliki 5293 


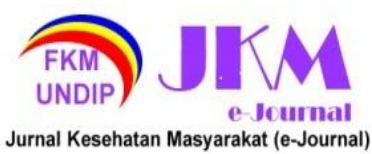

jumlah PUS dengan jumlah kunjungan sebanyak 1300 orang, namun hanya 53 PUS yang telah melakukan deteksi dini kanker servik dengan metode IVA. Namun karena cakupan pemeriksaan tes IVA dan pap smear yang masih kurang yaitu hanya $0,98 \%$ PUS yang melakukan pemeriksaan, peneliti berusaha menganalisis bagaimana bisa meningkatkan cakupan pemeriksaan tes IVA dan pap smear di Kecamatan Benteng.

Dari hal tersebut dapat diketahui bahwa cakupan pemeriksaan tes IVA dan pap smear di kecamatan Benteng masih kurang dan sangat minim. Hal ini disebabkan karena sebagian pasangan usia subur (PUS) yang berada di Kecamatan Benteng masih kurang mengetahui bahaya akan kanker serviks, dan bagaimana pemeriksaan tes IVA dan pap smear itu sendiri. Adapun yang paham dan tahu mengenai kanker serviks dan pemeriksaannya, tidak mau melakukan pemeriksaan tes IVA dan dan pap smear. Hal ini dikarenakan ibu-ibu PUS merasa malu dan tidak nyaman jika diperiksa karena dilakukan pada organ kewanitaan bagian dalam.

Berdasarkan latar belakang diatas peneliti ingin melakukan penelitian tentang "Analisis Cakupan pemeriksaan IVA Test dan Pap Smear Pada Pasangan Usia Subur di Kecamatan Benteng Kepulauan Selayar Tahun 2021 yang bertujuan untuk mengetahui bagaimana cakupan pemeriksaan IVA test dan Pap Smear pada pasangan usia subur di Kecamatan Benteng Kepulauan Selayar Tahun 2021.

\section{METODE PENELITIAN}

Jenis penelitian yang digunakan adalah metode observasional dengan pendekatan deskriptif analitik yaitu dengan rancangan penelitian cross sectional yang bertujuan untuk mengetahui cakupan pemeriksaan tes IVA dan pap smear pada PUS di Kecamatan Benteng. Penelitian ini dilaksanakan pada tanggal 20 Mei 2021 sampai 18 Juni 2021 di Puskesmas Benteng Kabupaten Selayar. Populasi dari penelitian ini adalah PUS (Pasangan usia subur) yang menjadi sasaran wilayah kerja Puskesmas Benteng di Kecamatan Benteng dengan jumlah populasi sasaran PUS sebanyak 1300 orang dengan sampel penelitian yang sesuai kriteria inklusi dan eksklusi yang akan dijadikan responden penelitian dengan 93 responden dengan Variabel yang digunakan dalam penelitian ini adalah variabel independent atau variabel bebas dan variabel dependent atau variabel terikat. Pada penelitian ini variabel bebas adalah usia, sikap, pengetahuan, pendidikan, dan dukungan suami. Variabel terikat pada penelitian ini adalah jumlah pemeriksaan iva test dan pap smear dengan menggunakan teknik pengumpulan data menggunakan lembar kuesioner dan hasil cakupan pemeriksaan tes IVA dan pap smear. Lembar kuesioner berisi pernyataan tentang IVA dan pap smear yang akan mengukur tingkat pendidikan, usia, sikap, dukungan suami dan pengetahuan. Sedangkan hasil cakupan pemeriksaan tes iva dan pap smear mencakup jumlah PUS yang melakukan pemeriksaan tes IVA dan pap smear.

\section{HASIL DAN PEMBAHASAN}

Hasil dari pengumpulan data ini disajikan dalam bentuk tabel yang terdiri dari hasil univariat dan bivariat dengan teknik chi-square. Analisis univariat akan dilakukan untuk mendeskripsikan masing-masing variabel dengan menggunakan distribusi frekuensi dengan ukuran persentase, sedangkan analisis bivariat akan dilakukan untuk melihat adanya hubungan antara variabel bebas dengan variabel terikat.

\section{Analisis Univariat}

Pada analisis univariat ini menghasilkan distribusi frekuensi dan persentase dari tiap variabel yang ada. Adapun variabel yang dianalisis dalam penelitian ini meliputi pemeriksaan IVA test dan pap smear, faktor pendorong (usia, pendidikan, pengetahuan, sikap, dan dukungan suami).

Tabel 1. Distribusi Frekuensi Responden Berdasarkan Usia, Pendidikan, Pengetahuan, Sikap, Dukungan Suami, Pemeriksaan IVA Test dan Pap Smear

\begin{tabular}{|c|c|c|c|c|c|c|c|c|c|}
\hline 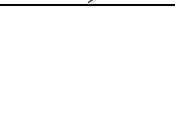 & Intervensi & 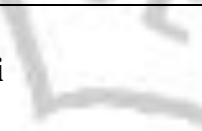 & $\mathbf{N}$ & Min & Max & Mean & $\begin{array}{c}\text { Standa } \\
\mathbf{r} \\
\text { Deviasi }\end{array}$ & Frekuensi & $\begin{array}{c}\text { Persentase } \\
(\%)\end{array}$ \\
\hline \multirow{2}{*}{ Usia } & & $\begin{array}{c}\text { Resiko } \\
\text { rendah } \\
(\leq 35 \text { tahun })\end{array}$ & \multirow{2}{*}{93} & \multirow{2}{*}{1,00} & \multirow{2}{*}{2,00} & \multirow{2}{*}{1,4946} & \multirow{2}{*}{,50268 } & 47 & 50.5 \\
\hline & & $\begin{array}{c}\text { Resiko } \\
\text { tinggi } \\
(\geq 35 \text { tahun })\end{array}$ & & & & & & 46 & 49.5 \\
\hline \multirow{2}{*}{\multicolumn{2}{|c|}{ Pendidikan }} & Dasar & \multirow{2}{*}{93} & \multirow{2}{*}{1,00} & \multirow{2}{*}{2,00} & \multirow{2}{*}{2,1183} & \multirow{2}{*}{,70479 } & 18 & 19.4 \\
\hline & & Menengah & & & & & & 46 & 49.5 \\
\hline
\end{tabular}


JURNAL KESEHATAN MASYARAKAT (e-Journal)

Volume 10, Nomor 1, Januari 2022

ISSN: 2715-5617 / e-ISSN: 2356-3346

http://ejournal3.undip.ac.id/index.php/jkm

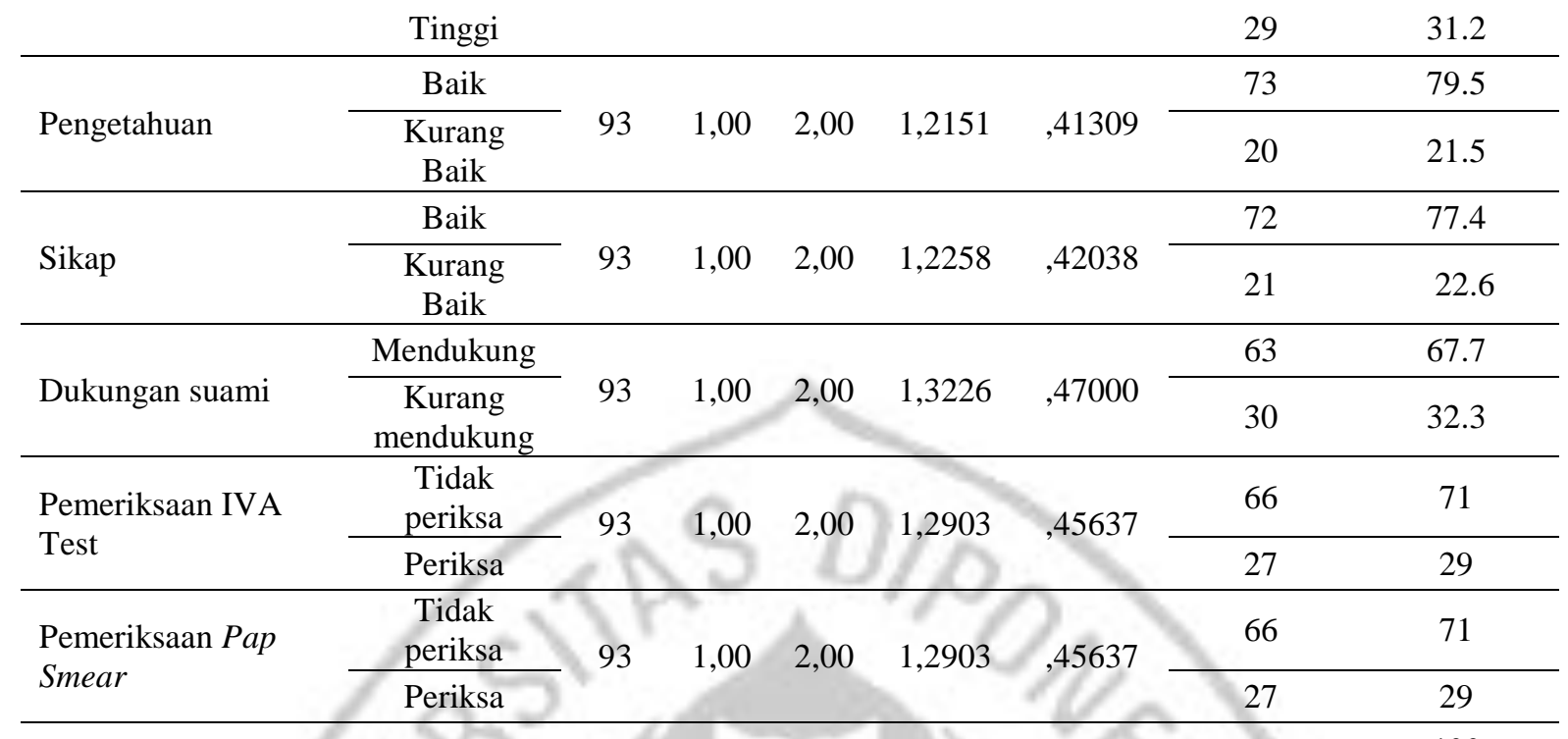

\section{Sumber : Data Primer, 2021}

Berdasarkan tabel diatas, menunjukkan bahwa responden yang berada di kategori resiko rendah memiliki jumlah sebanyak 47 orang dengan jumlah persentase $50,5 \%$. Sedangkan responden yang berada di kategori resiko tinggi memiliki jumlah sebanyak 46 orang dengan jumlah persentase $49,5 \%$. Adapun untuk responden yang berada di kategori dasar memiliki jumlah sebanyak 18 orang dengan jumlah persentase $19,4 \%$. Sedangkan responden yang berada di kategori menengah memiliki jumlah sebanyak 46 orang dengan jumlah persentase $49,5 \%$ dan untuk responden yang berada di kategori tinggi memiliki jumlah sebanyak 29 orang dengan jumlah persentase $31,2 \%$.

Untuk pengetahuan menunjukkan bahwa responden yang berada di kategori baik memiliki jumlah sebanyak 73 orang dengan jumlah persentase $78,5 \%$. Sedangkan responden yang berada di kategori kurang baik memiliki jumlah sebanyak 20 orang dengan jumlah persentase 21,5 \% . Selanjutnya untuk dari segi sikap responden yang berada dalam kategori memiliki jumlah sebanyak 72 orang dengan jumlah persentase $77,4 \%$. Sedangkan responden yang berada di kategori kurang baik memiliki jumlah sebanyak 21 orang dengan jumlah persentase $22,6 \%$.

Kemudian untuk kategori dukungan suami, responden yang berada di kategori mendukung memiliki jumlah sebanyak 63 orang dengan jumlah persentase $67,6 \%$. Sedangkan responden yang berada di kategori kurang mendukung memiliki jumlah sebanyak 30 orang dengan jumlah persentase $32,3 \%$.

Dan adapun untuk pemeriksaaan Test IVA dan pemeriksaan Pap Smear responden yang berada di kategori tidak periksa memiliki jumlah sebanyak 66 orang dengan jumlah persentase $71,0 \%$. Sedangkan responden yang berada di kategori periksa memiliki jumlah sebanyak 27 orang dengan jumlah persentase $29,0 \%$.

\section{Analisis Bivariat}

Analisis bivariat dalam penelitian ini untuk mengetahui bagaimana hubungan antara variabel bebas (usia, pendidikan, pengetahuan, sikap, dan dukungan suami) dengan variabel terikat (cakupan pemeriksaan IVA test dan pap smear).

Dalam penelitian ini digunakan uji statistik kai kuadrat (chi square) karena masing-masing variabel sudah dikategorikan. Apabila nilai $\mathrm{p}$ value $\leq 0,05$ maka keputusannya adalah Ho ditolak yang artinya ada perbedaan proporsi antara variabel independen dengan variabel dependen, atau berarti ada hubungan yang signifikan. Tetapi apabila nilai $\mathrm{p}$ value $>0,05$ maka keputusannya Ho gagal ditolak yang dapat diartikan tidak ada perbedaan proporsi antara variable independen dengan variable dependen, atau berarti tidak ada hubungan yang signifikan ${ }^{7}$. 


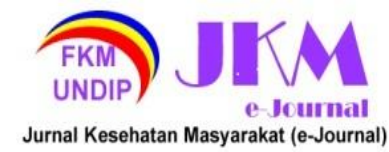

JURNAL KESEHATAN MASYARAKAT (e-Journal)
Volume 10, Nomor 1, Januari 2022
ISSN: 2715-5617 / e-ISSN: 2356-3346
http://ejournal3.undip.ac.id/index.php/jkm

Tabel 2. Distribusi Berdasarkan Hubungan Usia, Pendidikan, Pengetahuan, Sikap, Dukungan Suami dengan Pemeriksaan IVA Test dan Pap Smear

\begin{tabular}{|c|c|c|c|c|c|c|c|}
\hline \multirow{3}{*}{\multicolumn{2}{|c|}{ Intervensi }} & \multicolumn{4}{|c|}{ Pemeriksaan Test IVA dan Pap Smear } & \multirow{2}{*}{\multicolumn{2}{|c|}{ Total }} \\
\hline & & \multicolumn{2}{|c|}{ Tidak Periksa } & \multicolumn{2}{|c|}{ Periksa } & & \\
\hline & & $\mathbf{n}$ & $\%$ & $\mathbf{n}$ & $\%$ & $\mathbf{n}$ & $\%$ \\
\hline \multirow{3}{*}{ Usia } & Resiko Rendah & 38 & 40,9 & 9 & 9,7 & 47 & 50,5 \\
\hline & Resiko Tinggi & 28 & 30,1 & 18 & 19,4 & 46 & 49,5 \\
\hline & Total & 66 & 71 & 27 & 29 & 93 & 100 \\
\hline \multirow{4}{*}{ Pendidikan } & Dasar & 11 & 11,8 & 7 & 7,5 & 18 & 19,4 \\
\hline & Menengah & 38 & 40,9 & 8 & 8,6 & 46 & 49,5 \\
\hline & Tinggi & 17 & 18,3 & 12 & 12,9 & 29 & 31,2 \\
\hline & Total & 66 & 71 & 27 & 29 & 93 & 100 \\
\hline \multirow{3}{*}{ Pengetahuan } & Baik & 48 & 51,6 & 25 & 26,9 & 73 & 78,5 \\
\hline & Kurang Baik & 18 & 19,4 & 2 & 2,2 & 20 & 21,5 \\
\hline & Total & 66 & 71 & 27 & 29 & 93 & 100 \\
\hline \multirow{3}{*}{ Sikap } & Baik & 47 & 50,5 & 25 & 26,9 & 72 & 77,4 \\
\hline & Kurang Baik & 19 & 20,4 & 2 & 2,2 & 21 & 22,6 \\
\hline & Total & 66 & 71 & 27 & 29 & 93 & 100 \\
\hline \multirow{3}{*}{ Dukungan } & Mendukung & 40 & 43 & 23 & 24,7 & 63 & 67,7 \\
\hline & $\begin{array}{c}\text { Kurang } \\
\text { Mendukung }\end{array}$ & & & & 4,3 & 30 & 32,3 \\
\hline & Total & 66 & 71 & 27 & 29 & 93 & 100 \\
\hline
\end{tabular}

Sumber : Data Primer, 2021

a. Hubungan Usia dengan Pemeriksaan Test IVA dan Pap Smear.

Berdasarkan tabel 2 diketahui bahwa sebagian besar responden yang tidak melakukan pemeriksaan test IVA dan Pap Smear berada pada kategori usia resiko rendah $(40,9 \%)$. Sedangkan sebagian besar responden yang melakukan pemeriksaan test IV dan Pap Smear berada pada kategori usia resiko tinggi $(19,4 \%)$.

Hasil analisis hubungan usia dengan pemeriksaan test IVA dan Pap Smear diperoleh nilai sebesar 0,029, dimana nilai $0,029<\alpha$ $(0,05)$. Karena nilainya lebih kecil dari 0,05 , maka Ho diterima. Hal ini menunjukkan bahwa ada hubungan antara usia dengan pemeriksaan test IVA dan Pap Smear pada PUS yang ada di Kecamatan Benteng Kepulauan Selayar.

b. Hubungan Pendidikan dengan Pemeriksaan Test IVA dan Pap Smear

Berdasarkan tabel 2 diketahui bahwa sebagian besar responden yang tidak melakukan pemeriksaan test IVA dan Pap Smear berada pada kategori pendidikan menengah $(40,9 \%)$. Sedangkan sebagian besar responden yang melakukan pemeriksaan test IV dan Pap Smear berada pada kategori pendidikan tinggi $(12,9 \%)$.

Hasil analisis hubungan pendidikan dengan pemeriksaan test IVA dan Pap Smear diperoleh nilai sebesar 0,049, dimana nilai $0,049=\alpha$ $(0,05)$. Karena nilainya sama dengan 0,05 , maka Ho ditolak. Hal ini menunjukkan bahwa tidak ada hubungan antara pendidikan dengan pemeriksaan test IVA dan Pap Smear pada PUS yang ada di Kecamatan Benteng Kepulauan Selayar

c. Hubungan Pengetahuan dengan Pemeriksaan Test IVA dan Pap Smear

Berdasarkan tabel 2 diketahui bahwa sebagian besar responden yang tidak melakukan pemeriksaan test IVA berada pada kategori baik (51,6\%). Sedangkan sebagian 


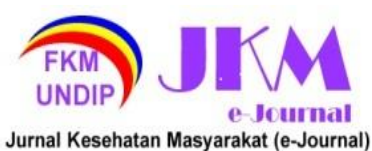

besar responden yang melakukan pemeriksaan test IVA berada pada kategori baik $(26,9 \%)$.

Hasil analisis hubungan pengetahuan dengan pemeriksaan test IVA diperoleh nilai sebesar 0,027 , dimana nilai $0,027<\alpha(0,05)$. Karena nilainya lebih kecil dari 0,05, maka Ho diterima. Hal ini menunjukkan bahwa ada hubungan antara pengetahuan dengan pemeriksaan test IVA pada PUS yang ada di Kecamatan Benteng Kepulauan Selayar

d. Hubungan Sikap dengan Pemeriksaan Test IVA dan Pap Smear

Berdasarkan tabel 5 diketahui bahwa sebagian besar responden yang tidak melakukan pemeriksaan test IVA dan Pap Smear berada pada kategori baik $(50,5 \%)$. Sedangkan sebagian besar responden yang melakukan pemeriksaan test IVA dan Pap Smear berada pada kategori baik (26,9\%). Hasil analisis hubungan sikap dengan pemeriksaan test IVA dan Pap Smear diperoleh nilai $\mathrm{p}$ sebesar 0,020 , dimana nilai $0,020<\alpha(0,05)$. Karena nilainya lebih kecil dari 0,05 , maka Ho diterima. Hal ini menunjukkan bahwa ada hubungan antara sikap dengan pemeriksaan test IVA dan Pap Smear pada PUS yang ada di Kecamatan Benteng Kepulauan Selayar

e. Hubungan Dukungan Suami dengan Pemeriksaan Test IVA dan Pap Smear

Berdasarkan tabel 2 diketahui bahwa sebagian besar responden yang tidak melakukan pemeriksaan test IVA dan Pap Smear berada pada kategori mendukung $(43,0 \%)$. Sedangkan sebagian besar responden yang melakukan pemeriksaan test IVA dan Pap Smear berada pada kategori mendukung $(24,7 \%)$.

Hasil analisis hubungan dukungan suami dengan pemeriksaan test IVA dan Pap Smear diperoleh nilai $\mathrm{p}$ sebesar 0,017 , dimana nilai $0,017<\alpha(0,05)$. Karena nilainya lebih kecil dari 0,05, maka Ho diterima. Hal ini menunjukkan bahwa ada hubungan antara dukungan suami dengan pemeriksaan test IVA dan Pap Smear pada PUS yang ada di Kecamatan Benteng Kepulauan Selayar.

\section{PEMBAHASAN}

\section{Hubungan Usia dengan Pemeriksaan Test IVA dan Pap Smear}

Berdasarkan hasil analisis, diketahui bahwa terdapat hubungan antara usia dengan pemeriksaan test IVA dan Pap Smear pada PUS yang ada di Kecamatan Benteng Kepulauan Selayar, dimana nilainya sebesar 0,029 lebih kecil daripada $\alpha(0,05)$. Hasil penelitian ini sesuai dengan Teori Green (1980) bahwa faktor sosiodemografi dalam hal ini umur berpengaruh terhadap perbedaan dalam perilaku kesehatan. Semakin muda wanita melakukan hubungan seksual maka semakin besar kemungkinan terjadinya kanker serviks. Sehingga, diharapkan untuk sejak dini atau secara rutin untuk melakukan pemeriksaan IVA sebagai bentuk upaya deteksi dini terhadap kanker serviks. Semakin tua seorang wanita maka makin tinggi risikonya terkena kanker serviks. Meskipun begitu, bukan berarti wanita muda tidak dapat terkena kanker serviks. Bahkan, yang memiliki usia muda jika ia tidak memiliki pola hidup yang sehat, maka dapat saja terkena kanker serviks. Pada usia $\geq 35$ tahun wanita mempunyai resiko 15,714 kali untuk terkena kanker serviks dibandingkan dengan wanita yang usia $<35$ tahun $^{8}$.

\section{Hubungan Pendidikan dengan Pemeriksaan Test IVA dan Pap Smear}

Berdasarkan hasil analisis, diketahui bahwa tidak terdapat hubungan antara pendidikan dengan pemeriksaan test IVA dan Pap Smear pada PUS yang ada di Kecamatan Benteng Kepulauan Selayar. Hasil penelitian ini sesuai dengan hasil penelitian Fibria, dkk (2019) bahwa secara analisis statistik, variabel pendidikan tidak memiliki hubungan dengan partisipasi pemeriksaan deteksi dini kanker dengan IVA dan pap smear maupun SADANIS $^{11}$. Hasil penelitian ini sama dengan hasil penelitian oleh Gustiana (2014) yang menyatakan tidak ada hubungan antara pendidikan dengan perilaku pencegahan kanker serviks. Penelitian lain dari Octavia (2009) menyatakan bahwa tidak ada hubungan antara pendidikan penelitian ini bisa jadi disebabkan karena mayoritas wanita usia subur di Kabupaten Bantul yaitu sebanyak 82,6\% berpendidikan lanjut, sehingga baik WUS yang pernah maupun belum pernah berparisipasi dalam deteksi dini kanker pada wanita sebagian besar memiliki pendidikan lanjut ${ }^{12}$.

Hubungan Pengetahuan dengan Pemeriksaan Test IVA dan Pap Smear

Berdasarkan hasil analisis, diketahui bahwa terdapat hubungan antara pengetahuan dengan pemeriksaan test IVA dan Pap Smear pada PUS yang ada di Kecamatan Benteng Kepulauan Selayar. Hasil penelitian ini sesuai dengan hasil penelitian Yuliwati (2012) bahwa bahwa secara statistik ada hubungan yang signifikan antara pengetahuan dengan perilaku WUS dalam periksa IVA $^{14}$. Proporsi WUS yang periksa IVA ditemukan lebih banyak pada WUS dengan pengetahuan baik sebanyak $37(66,1 \%)$, sedangkan proporsi WUS yang tidak periksa IVA lebih banyak ditemukan pada WUS yang berpengetahuan kurang sebanyak $105(67,3 \%)$. Hasil penelitian ini sejalan dengan penelitian Chusniah (2016) bahwa terdapat hubungan tingkat pengetahuan WUS dengan 


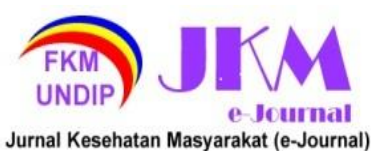

pemeriksaan IVA dan Pap-smear dalam upaya deteksi dini kanker serviks $(p=0,000){ }^{15}$ dan penelitian yang dilakukan (Wulandari, 2017) menyatakan bahwa terdapat hubungan yang signifikan antara tingkat pengetahuan kanker serviks dengan perilaku ibu-ibu dengan melakukan IVA atau pap smear di mana diperoleh p value $=0,027<$ $0,05^{16}$.

\section{Hubungan Sikap dengan Pemeriksaan Test IVA dan Pap Smear}

Berdasarkan hasil analisis, diketahui bahwa terdapat hubungan antara sikap dengan pemeriksaan test IVA dan Pap Smear pada PUS yang ada di Kecamatan Benteng Kepulauan Selayar. Hasil penelitian ini sesuai dengan hasil penelitian Handayani (2018) bahwa ada hubungan yang signifikan antara sikap dengan perilaku pemeriksaan IVA pada WUS di desa Penyak kecamatan Koba kabupaten Bangka Tengah Tahun 2017 diperoleh nilai $\rho=0,000^{8}$. Hal ini dikarenakan ibu yang mempunyai sikap tidak mendukung, berisiko 7,367 kali lebih besar untuk tidak melakukan pemeriksaan IVA dibandingkan dengan ibu yang memiliki sikap yang mendukung. Sakanti (2007) menyatakan bahwa seluruh wanita yang melakukan pemeriksaan deteksi dini kanker leher rahim memiliki sikap yang positif terhadap deteksi dini kanker leher Rahim ${ }^{10}$. Sarini (2011) juga mengatakan bahwa tidak semua wanita yang bersikap positif melakukan pemeriksaan deteksi dini kanker serviks ${ }^{18}$.

Hubungan Dukungan Suami dengan Pemeriksaan Test IVA dan Pap Smear

Berdasarkan hasil analisis, diketahui bahwa terdapat hubungan antara dukungan suami dengan pemeriksaan test IVA dan Pap Smear pada PUS yang ada di Kecamatan Benteng Kepulauan Selayar. Hasil penelitian ini sesuai dengan hasil penelitian Yuliwati (2012) bahwa ada hubungan yang signifikan antara dukungan suami/keluarga dengan perilaku periksa IVA $(p=0,000){ }^{14}$. Didapatkan PR 5,587 menunjukkan bahwa yang mendapatkan dukungan baik dari suami berpeluang 5,587 kali lebih besar untuk berperilaku IVA baik. Penelitian ini sejalan dengan penelitian Purba (2011) yang menyatakan bahwa faktor penting dalam memberikan dorongan bagi ibu untuk melakukan pemeriksaan deteksi dini kanker leher rahim adalah orang-orang terdekat yaitu suami dan keluarga. Peran suami dan keluarga sangat kuat dalam memberikan dukungan bagi ibu untuk melakukan pemeriksaan kesehatan sehingga sangat mempengaruhi status kesehatannya ${ }^{19}$.

Dukungan suami merupakan salah satu bentuk motivasi untuk melakukan pemeriksaan IVA yang diberikan oleh suami. Peran keluarga sebagai kelompok kecil yang terdiri individu-individu yang mempunyai hubungan satu sama lain, saling tergantung merupakan sebuah lingkungan sosial dimana secara efektif keluarga memberi perasaan $\operatorname{aman}^{22}$.

\section{KESIMPULAN}

Merujuk pada hasil analisis dan pembahasan/hipotesis, maka peneliti mengambil kesimpulan sebagai berikut:

1. Sebagian besar responden tidak melakukan pemeriksaan test IVA dan pap smear. Mayoritas responden adalah berisko rendah, berpendidikan menengah, berpengetahuan baik, bersikap baik, dan mendapatkan dukungan dari suami.

2. Terdapat hubungan yang signifikan antara usia, pengetahuan, sikap, dan dukungan suami dengan pemeriksaan test IVA dan pap smear.

3. Tidak ada hubungan yang signifikan antara pendidikan dengan pemeriksaan test IVA dan pap smear.

4. Faktor yang paling berpengaruh terhadap pemeriksaan test IVA dan pap smear pada pasangan usia subur di kecamatan benteng kepulauan selayar tahun 2021 adalah dukungan suami.

\section{Ucapan Terimakasih}

Peneliti mengucapkan banyak terimakasih kepada semua pihak yang telah membantu dalam menyelesaikan penelitian dan penulisan artikel ini.

\section{DAFTAR PUSTAKA}

1. Depkes RI, (2015). Situasi Penyakit Kanker. Jakarta: Pusat Data dan Informasi Kemenkes.

2. Yayasan Kanker Indonesia (YKI), (2012). Penderita Kanker di Indonesia. Dari Yayasan kanker indonesia.org/2012/yki-race/. [di akses 24 Februari 2017].

3. Syahrir, dkk, (2015). Profil Kesehatan Sulawesi Selatan 2014. Makassar: Dinas Kesahatan Sulawesi Selatan.

4. Komite Penanggulangan Kanker Nasional (2015). Panduan Penatalaksanaan Kanker Serviks. Jakarta: Kementerian Kesehatan RI.

5. Arsanti, Tuti Indra, (2014). Tingkat Pengetahuan WUS tentang Pemeriksaan Pap Smear di Dusun Kedon Desa Congkrang, Kecamatan Muntilan Kabupaten Magelang. KTI. Program Studi DIII Kebidanan Stikes Jendral Achmad Yani. Yogyakarta.

6. Nisa, Widiya, dkk, (2019). Jurnal Kesehatan Global. Faktor Yang Memengaruhi Pemanfaatan Inspeksi Visual Asam Asetat (IVA) Pada Wanita Usia Subur di Wilayah Kerja Puskesmas Mandala Kecamatan Medan Tembung Kota medan. [online] Vol. 2, No. 2, Mei 2019: 71-80. 


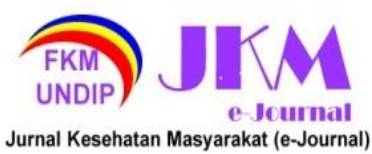

http://ejournal.helvetia.ac.id/index.php/jkg/artic le/viewFile/4252/219. [diakses 2 april 2020].

7. Hastono.S, dan Sabri Luknis. 2010. Statistik Kesehatan. Jakarta: Rajawali Pers.

8. Handayani, S. D. (2018). Faktor-Faktor Yang Mempengaruhi Perilaku Pemeriksaan Iva Pada Wanita Usia Subur Di Desa Penyak Kecamatan Koba Kabupaten Bangka Tengah Tahun 2017. Skripsi. [online]. http://eprints.poltekkesjogja.ac.id. [diakses tanggal 27 juli 2021].

9. Sarafino, Edward P. (1994). Health Psychologi, Biopsychosocial Interaction. Edisi kelima. New York: John Wiley \& Sons, Inc.

10. Sakanti (2007). Faktor-faktor yang Berhubungan dengan Perilaku Pemeriksaan Pap Smear pada Wanita Usia Subur di Puskesmas Kecamatan Makasar Tahun 2007, Jakarta: Skripsi FKM UI.

11. Fibria, I.S. Pramesti, dkk. (2019). Faktor-Faktor yang Mempengaruhi Partisipasi Wanita Usia Subur Dalam Pemeriksaan Deteksi Dini Kanker Pada Wanita di Kabupaten Bantul Tahun 2019. Skripsi. [online]. http://eprints.poltekkesjogja.ac.id/. [diakses tanggal 27 Juli 2021].

12. Octavia C. (2009) Gmbaran Pengetahuan Ibu Mengenai Pemeriksaan Pap smear di Kelurahan Petisah Tengah Tahun 2009. USU :1-8

13. Darnindro, N. (2016). Pengetahuan sikap perilaku perempuan yang sudah menikah mengenai pap smear dan faktor-faktor yang berhubungan di rumah susun klender jakarta 2006. USU.

14. Yuliwati. (2012). Faktor-faktor Yang Berhubungan Dengan Perilaku Wus Dalam Deteksi Dini Kanker Leher Rahim Metode Iva Di Wilayah Puskesmas Prembun Kabupaten Kebumen. Skripsi. Fakultas Kesehatan Masyarakat Program Studi Sarjana Kesehatan Masyarakat Peminatan Kebidanan Komunitas Universitas Indonesia. [online]. http://lontar.ui.ac.id. [diakses 9 April 2020].
15. Chusniah, R. Windi. (2016). Pengaruh Pendidikan Kesehatan Tentang Iva Dan PapSmear Terhadap Tingkat Pengetahuan Dan Sikap Wus Melalui Media Leaflet Berkalender Dalam Upaya Deteksi Dini Kanker Serviks Di Wilayah Kerja Puskesmas Manahan Kota Surakarta. Publikasi Ilmiah. [online]. http://eprints.ums.ac.id/. [diakses tanggal 27 Juli 2021].

16. Wulandari, R. W. (2017). Dengan Perilaku Melakukan Iva Atau Pap Smear Pada Ibu-Ibu Usia 25-50 Tahun Di Dusun Greges Donotirto Kretek.Yogjakarta

17. Nuranna, L. 2008. Skrining Kanker Serviks dengan Metode IVA.Jurnal Dunia Kedokteran.

18. Sarini, N (2011). Faktor-Faktor Yang Berhubungan Dengan Pemeriksaan Pap Smear Pada Wanita Usia Subur Di Desa Pacung. http://repository.ui.ac.id. [diakses pada tanggal 27 Juni 2017].

19. Purba, Evi Misrawaty. (2011). Faktor-Faktor yang Berhubungan dengan Pemeriksaan Papsmear pada Pasangan Usia subur (PUS) di Puskesmas Belawan Kota Medan Tahun 2011. Skripsi : FKM UI

20. Wahyuni, S. (2013). Faktor - Faktor Yang Mempengaruhi Perilaku Deteksi Dini Kanker Serviks Di Kecamatan Ngampel Kabupaten Kendal Jawa Tengah. Jurnal Keperawatan Maternitas. No 1 Vol 1: 55- 60.

21. Marlina, Eli. (2014). Hubungan Dukungan Suami Dengan Perilaku Istri Melakukan Pemeriksaan Pap Smear Di Puskesmas Umbulharjo Ii Kota Yogyakarta Tahun 2014. [online] Naskah Publikasi. Program Studi Bidan Pendidik Jenjang D Iv Sekolah Tinggi Ilmu Kesehatan 'Aisyiyah Yogyakarta. http://digilib.unisayogya.ac.id/959/1/naskah\%2 Opublikasi.pdf. [diakses 24 Juli 2021].

22. Priyoto. (2014). Teori Sikap dan Perilaku dalam Kesehatan. Yogyakarta: Nuha Medika.

23. Sitti, Saleha, (2009). Asuhan Kebidanan Masa Nifas. Salemba Medika: Jakarta 